\title{
THE GIFT OF CREATIVITY \\ in TWO POEMS by W. H. AUDEN
}

\author{
Zióle Zanotto Malhadas \\ Universidade Federal do Paraná \\ Auden represents the sensibility - at the \\ mercy of a set of principies - the artist \\ working In the service of a cause... - \\ (Cleanth Brooks)
}

Poetry is a not a science - cold and precise, but an art. The poet does not create ideas, but words, according to J. Cohen's opinion. Thus, the art of poetry has its own task: - to transform the raw material - the verbal code - into a "work of art", i.e., a poem.

Talking about his aim as a poet, W. H. Auden said that he looked for

a style which shall combine the drab sober truthfulness of prose with a poetic uniqueness of expression...

Whatever else it may or may not be, 1 want every poem I write to be a hymn in praise of the English language; 1

As a poet, he respects and admires "the novelist", who is able to create characters, and "the composer", who is able to create music. But, he is aware that in this keen relationship between Art and the Artist there are other problems involved.

Art is not enough. Art - poetry - is interesting and perhaps important: but in what sense is it finally meaningful to the individual soul before God - not only to the individual reader, but to the individual creator, the poet himself? It makes nothing happen.

... Poetry is a game of knowledge."

If poetry is a game of knowledge, Auden makes use of his knowledge "in the service of a cause", as we see in the poems "The NOVELIST" and "The COMPOSER", which we are going to analyse in the following levels:

1 - Realization (Graphology and Phonology)

2 - Form (Morphology and Syntax)

3 - Semantics

1 Spears, Monroe K. The poetry of W. H. Auden. Iondon, Oxford University Pres, 1968. p. vil.

2 HOGGART. Richnrd. Introduction to Auden's poetry. In: SPEARS, Monroe $K$. Auden: a collection of critical essays. Fnglewood Cliffs, Prentice Hall, 1964. p. 128. 
These poems are part of Auden's mid-thirties production "1933 - 1938", and were published in "New Writings" (Spring 1939, AT-CSP50, p. 124-5).

Since the boundaries between the levels of Realization, Form and Semantics are not clearly distinct - they are interrelated, one field penetrates the other and all the eiements are related in a unit, we are going to consider these poems as a "functioning totality". ${ }^{3}$

This definition of a poem as a "functioning totality" is used by Delas \& Filliolet in "Linguistique et Poétique". According to them $i_{i}$ is only in the poetical text that the language is not used as a support of speech, but as a constituent part of the message

The definition has its roots in Jakobson's statements:

- the poetic function is the aim of the message;

- the poetic function projects the principle of equivalence from the axis of selection into the axis of combination.

Then, a poem, as a unit, is more than the simple sum of its elements, because there is an intrinsic relationship between its parts

\section{THE NOVELIST}

1 Encased in talent like a uniform,

2 The rank of every poet is well known;

i They can amaze us like a thunderstorm,

4 Or die so young, or live for years alone.

5 They zan dash forward like hussars: but he

6 Must struggle out of his boyish gift and learn

- How to be plain and awkward, how to be

8 One after whom none think it worth to turn

9 For: to achieve his lightest wish, he must

ic Become the whole of boredom, subject to

11 Vulgar complaints like love, among the Ju=1

12 Be just, among the Filthy filthy too,

13 And in his own weak person, if he can,

14 Must suffer dully all the wrongs of Man.

\section{W. A. Auden} 3 DFLAS, Daniel \& FILLIOLET. Jacques. Lincäiatica poétien. São Paulo, Cultrix.
1975. p. 66.

4 DElas Filliolet, p. 54-5. 


\section{1 - LEVEL of REALIZATION}

1.1 - Graphology: "The Novelist" has the regular and traditional form of a Sonnet: 14 verses divided into 4 stanzas, with $4-4-3-3$ lines.

In the two last stanzas, the poet makes use of capital letters in "Just, Filthy, Man", in an attempt of furning concrete the ideas evoked by the abstract nouns.

1.2 - Phonology: Analysing the rhyme of this poem, we perceive the consonant rhyme and the incidence of the nasal sound $/ \mathrm{n} /$, which appears 6 times in final position, plus 3 times in internal position:

- consonance $=10 / \mathrm{n}-\mathrm{m}-\mathrm{t} /$

- assonance $=4 / i-o /$

Rhythm - The regularity of the sound pattern, the decassylabic line, in relation to the stressed syllables - also regular: 5 stressed syllables each line - reveals a rhythm similar to normal speech.

Summarizing the phonological level of this poem, we can detach:

a) the high incidence of the nasal consonant $/ \mathrm{n} /$, repeated 30 times throughout the poem;

b) the recurrence of the central vowe $\wedge /$ in "but, must, just, vulgar, subject, suffer, dully".

c) the repetition of the liquid consonant /// in "talent, like, well, live, alone, learn, plain, lightest, love, filthy, dully", which gives to the poem a fluid quality reinforced by the open diphtong, / $\mathrm{a}^{\mathrm{I}} /$, which suggests 'softness', as in "like, d'e, lightest".

\section{2 - LEVEL Of FORM}

The Syntactical and Morphological aspects of "The Novelist" piesent several interesting elements that can be considered as "foregrounded" according to $C$. Leech. "

A device that performs here an important role is "parallelism", which seems to be used by the poet as a 'bridge' linking the

3 LEECH. Conffer N. A IInguistie quide to Englah poetry. London, Longman, 1969. p. $\mathbf{8 6 - 7 .}$ 
three main levels: Realization, Form and Semantics (or sound, structure and meaning).

\section{a - Line 4 - "Or die so young, or live for years alone"}

This alliteration "or die... or live" brings out an antithesis: die $X$ live, which emphasizes the "parallelism" - acco:ding to Jakobson's theory that there must be an element of identity and an element of contrast. 6

Semantically it seems to offer a choice to the poet, who is "encased in talent" ... "or die so young, or live for years alone"; there is not a happier alternative.

b - Lines 3 and 5 - "They can amaze us like a thunderstorm" ... "They can dash forward like hussars"

Besides para!le':ism, the phonological aspect is foregrounded by the repetition of the initial words, plus the word "like", which brings forth a "simile" (comparison).

The stiucture of the two sentences are similar, where the two verbs - "amaze / dash" - occupy the same position and are also semantically related, as we shall see later on, on the paradigmatic level.

This kind of recurrence on different levels - phonological, formal (syntactical) and seman.ical - is called "coupling" by Samuel Levin, who says: coupling serves to unify a poem. ${ }^{7}$

\section{c - Lines 7 and 8 - "How to be plain and awkward, how to ba One after whom none think it worth to turn"}

Parallel am occurs here in the same line, as a kind of "epanalepsis" (repeats: a ... a): but it is linked to the next line by the "enjambment", and semantically related by a "pleonasm" 8

There is also the repetition of the sound $/ t /$, which gives a curious effect to the end of line 8 , when it is opposed to the "th" sound $/ e /:$... "think if worth to turn".

$$
\begin{array}{r}
d-\text { Lines } 11 \text { and } 12-\text { "...like love, among the Just } \\
\text { Be just, among the Filthy filthy too," . }
\end{array}
$$

Here, in "like love", we have a "chiming: the device of connec-

6 JAKOBSON. Roman. Lintüistica e commnicaçāo. São Paulo. Cultrix, 1075. .p. 65. See also LEECH.

7 LEVIN, Samuel. Esstraturas lingüisticas em poesia. Sāo Paulo, Cultrix, 1975. p. 64. 8 LEECH, p. 82-132. 
ling two words by similarity of sound so that you are made to think of their possible connections". 0

We have also a sequence of two clauses with identical structures - parallelism and 'enjambment':

"among the Just, be just,

among the Filthy filthy too,"

where the poet repeats the same word but with a different function: Just (Noun) and just (adjective), Filthy (Noun) and filthy (adjective).

Thus, we have again a "coupling" - correspondence in sound, form and meaning; which is semantically present - also through the contrastive elements: JUST $\times$ FILTHY; their meanings evoke the versati!ity of the novelist.

A process of continuity is clearly perceived, not only in the 3rd. and 4th. stanzas, which are definitely interrelated as if it were a single paragraph, but also through the incidence of "enjambment":

- this device is used to link all the four lines of the 2 nd. stanza, as well as the lines of the $3 r d$. and 4 th. stanzas.

Such process of continuity reinforces the idea of the rhythm similar to normal speech or to 'novel' reading.

On the Morphological aspect, Auden has a special care with "Nouns" and "Verbs", which are well-balanced in number and associated even on the paradigmatic level.

These Nouns and Verbs reveal a triadic symmetry, related in form and semantic:

\section{NOUNS}

"talent
poet
gift
"uniform
rank
hussars
"plain
awkward
Filthy

$$
\begin{aligned}
& \text { artist's } \\
& \text { suffering }
\end{aligned}
$$

poet's

high rank

novelist's
suffering

\section{VERBS}

die struggle (out) suffer"

encased dash (forward) amaze"

learn

turn become"

This diagram leads us to Jakobson's concept of the "poetic function" - the projection of the principle of equivalence from the axis 9 LEECH, p. $05-6$. 
of selection into the axis of combination, thus the equivalence is promoted to the constitutive device of the sequence. ${ }^{10}$

We have to consider the "pronouns" too:

- the treatment is "he" in this poem, where the poet seems to be a lawyer defending his friend novelist and revealing "all the wrongs" he "must suifer".

\section{3 - LEVEL of SEMANTICS}

The "triadic symmetry" (see diagram above) gives us a general picture of the meaning of "The Novelist", where Auden claims the Artist's faith.

In the 1st. stanza, Auden reveals that the poet, in spite of his talent and high rank, is imprisoned "encased", he has not any other alternative: "Or die so young, or live for years alone."

However, the pictures he presents in the next stanzas are even worst. Now, he refers to the Novelist's faith, which does not look better than the Poet's doom.

The novelist "must struggle out of his boyish gift and learn...", which suggests that the 'gift of creativity' is really a heavy burden.

Auden does not mention any kind of reward - the artist works only to satisfy his internal impulses.

After enumerating all the suffering the novelist has to endure, when he decides "to be one after whom none think it worth to turn", Auden reinforces the idea of bitterness and distress, in the .ast stanza, saying that the novelist "must suffer dully all the wrongs of Man."

In order to describe human sentiments, the writer has to feel them deeply. He needs to experience suffering to be able to write about "all the wrongs of Man".

The poem also evokes the versatility of the novelist, who must "among the Just be just, among the Filthy filthy too", because, according to J. Byley

'Auden has always venerated this form of art, in which the phenomenology of life can be seen steadly and commented on 'in extrenso' - he calls it 'a higher a:t than poetry altogether'. ${ }^{11}$

10 JAKOBSON, p. 130.

11 BAYLEY, Jahn. W. H. Aluden. In: SPEARS, Auden, p. 68-9. 


\section{THE COMPOSER}

1 All the others translate; the painter sketches

2 A visible world to love or reject;

3 Rummaging into his living, the poet fetches

4 The images out that hurt and connect.

5 From Life to Art by painstaking adaption

6 Relying on us to cover the rift;

7 Only your notes are pure contraption,

8 Only your song is an absolute gift.

9 Pour out your presence, $O$ delight, cascading

10 The falls of the knee and the weirs of the spine,

11 Our climate of silence and doutb invading;

12 You alone, alone, $O$ imaginary song,

13 Are unable to say an existence is wrong,

14 And pour, out your forgiveness like a wine.

W. H. Auden

\section{1 - LEVEL Of REALIZATION}

1.1 - Graphology: "The Composer" is a Sonnet, but its 14 verses are divided into two stanzas: the first has 8 lines and the second 6 lines.

Capital letters are used in the ist, stanza, line 5: "From Life to Art...", giving concreteness to the abstract ideas of life and art.

Line 9: "O delight, cascading ...", and -

Line 12: "O imaginary song, ...", the capital letter fore. grounds an exclamation.

1.2 - Phonology: RHYME: The sonorous texture of the rhyming words in "The Composer" has a rich and peculiar affect, as we see

a) in the 1st. stanza, the recurrence of plosive and affricate voiceless consonants, forming clusters, foregrounds their 'hardness':
a - Lines 1.3: "sketches - fetches"
[tSz]
b - Lines 2.4: "reject - connect"
[kt]
c - Lines 5-7: "adaption - contraption
$d$ - Lines 6.8: "rift - gift"
$[\mathrm{ft}]$ 
According to $G$. Leech, there is o scale of increasing hardness of English consonants, where the affricates $/ t /$ and the plosives $/ p / t / k /$ are at the top. ${ }^{12}$

The peculiar feature of this thyme is also due to the repetition of the vowe $/ \Sigma /$, i.e., the 'hardness' of the consonants is intensified by the mutability from the open vowel /E/ to the strong consonant clusters (lines 1-2-3-4-:

- "sketches, fotches - reject, connect"

b) in the 2 nd. stanza the phenomenon is quite different: the Rhyme becomes 'softer', because of the repetition of the nasal sounds / $/ \mathrm{n} /$ and $/ \mathrm{ng} / \mathrm{in}$ opposition to the sonorous vowels $/ \mathrm{i} / \mathrm{o} /$ and the diphong $/ \mathrm{al} /$, which corroborates the 'softness' of rhymes:

$$
\begin{array}{ll}
\text { a - Lines 9-11: "cascading - invading" } & \text { [ing] } \\
\text { b - Lines 10-14: "spine - wine" } & \text { [aIn] } \\
c \text { - Lines 12-13: "song - wrong" } & \text { [ong] }
\end{array}
$$

c) There is also kind of internal rhyme, which intensifies the musicality of this poem, through the repetition of the same final sound in "presence - silence - existence" This resonance reveals also a semantic relationship: since the ides of "presence" of music is opposed to the idea of "silence" absence of sound, which is reinforced by the idea of "... unable to say an existence is wrong."

d) The repetition of the front-close vowel $/ i /$, in "into, visible, his, living, rift, gift, is" plus the incidence of the centralopen diphtong / $\mathrm{a} /$ in "delight, spine, climate, silence, like, wine", brings out a contrasting sonority, due to the different points of articulation of this vowel and this diphtong: close $X$ open.

Rhythm - "The Composer" is characterized by a "rising rhythm": the anapaest measure, ${ }^{13}$ which conveys a dynamic and vibrating musical effect as a homage to the man who is able to create music.

The metrical structure reveals 4 or 5 stressed syllables each verse, as we see in the 1 st. stanza, lines $1-2 ; 3-4$ :

12 LEECH. p. 98.

18 LEECH. p. 112-t. 
"All the óthers translaté: the páinter skétches A visible wórlder to lóve or rejéct;"

Rúmmaging into his living, the póet fétches

The ímages out that húrt and connéct."

\section{2 - LEVEL Of FORM}

"Parallelism" is a constant in this poem. The "foregrounding" of Syntactical and Morphological elements will be analysed here through the "parallelisms", which play a really important role, because, according to $G$. Leech

- "paralleslism is the aspect of poetic language which most obviously relates it to music." 14

Then, "The Composer" is a musical poem, as we see through the following parallelisms:
a) Lines 7-8:
"Only your notes are pure contraption," "Only your song is an absolute gift." (Adv. Pr. N. V. Obj.) = Form

These lines are linked not only by the identical syntactic structure (form), but also by the "anaphora", which evokes Hopkins defirition of verse as a speech that repeats, total or partially, the same Fhonic figure. ${ }^{15}$

We have here againt what S. Levin calls "coupling", through the correspondences of phonological, syntactical, morphological and semantical levels:

- Besides "anaphora" (the repetition of the 1st. and 2 nd. words), we have "synecdoche" in the words "notes" and "song", because notes are part of a song; and also "chiasmus": the letters $/ \mathrm{n} / \mathrm{o} / \mathrm{s} /$ of "notes" are inverted in "song".

- Semantically, "notes", while part of a musical code, are bound to innumerable combinations. According to the poet, "... no"es are pure contraption", which contains the idea of creativity that links this expression to its correspondent in the next structure "... an absolute gift".

Then, creativity is God's gift to man - the object of creativity is the aim of the artist, who only achieves his goal through

14 IFECH, D. 93.

15 JAKOBSON, p. 131. 
suffering: "From Life to Art by painstaking adaption." (line 5)

b) - Lines 9-14: "Pour out your presence, $O$ delight, cascading" "And pour out your forgiveness like a wine."

Another beautiful parallelism or "counpling" that brings harmony to the musicality of this poem, associating the syntagm to the paradigm:

"Pour out your presence, 0 delight...
land) pour out your forgiveness

- These lines have a similar structure, forming "anaphora", except for the "and" that appears in the initial position of the last verse, and links it to all the obthers.

- The repetition of the three initial words, besides presenting a strong musical effect, in the phonological aspect, it also has an inferesting visual effect, in the graphological aspect: "P OU $R$ OU T Y OU R"... We visualize here a triple "chiasmus": the letters "O, $U$ " appear in the three words, and the final " $R$ " in two of them.

- The poet is speaking directly to "The Composer", as if they were face to face, when ha says: "your presence, your forgiveness, (your notes, your song)."

- On the Syntactical level, the abstract nouns: "presence" and "forgiveness" occupy the same position, but they are semantically tifferent; However, each one is related to another abstract noun, in the paradigm:

(line 9) "presence" - > "existence" (line 13)

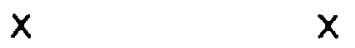

(line 14) "forgiveness" $->$ "silence" (line 11)

- As for the last expressions of these syntagms, we have an aliiteration in "O deLIGHT" - "LIKE a wine" and the tr ple repetition of the diphtong $/ \mathrm{a}^{\mathrm{I}}$. which b:ings out a fluid quality in the musical etructure, evoking the idea of liquid.

- In the Semantical level, the idea of liquid is also present in "pour out... wine", which can be associated to "forgiveness", evoking the Holy Eucharist in the Christian ritual of the Mass. 


\section{3 - LEVEL Of SEMANTICS}

We have to take into account the phonological, graphological, syntactical, and morphological aspects of this poem, whose foregrounded elements point to the "musicality" of "The Composer".

We perceive a kind of 'metalanguage', because it evokes an 'opera overture': the hardness of the first stanza suggests an opera singer declaiming the introduction - 'high chords'.

Hard stressed syllables, strong musical effects and densely meaningful words, deliberately selected by the poet, seem to symbolize the suffering process of 'creation': the composer striving hard for the "imaginary song".

And then, in the second stanza, it comes out and the 'music' Hlows, or "pouds) out ... like a wine".

It is evident that Auden is paying a tribute to the composer, when he says: "Only your notes are pure contraption, only your sung is an absolute gift."

However, he seems to pity the composer, when he says: "You alone, alone ... are unable to say an existence is wrong".

We have again the idea that 'creativity' is a gift, but the artist only achieves his goal through suffering.

Music, "O delight, cascading the falls of the knee and the weirs of the spine" is the result of "pure contraption".

\section{CONCLUSION:}

In the two poems Auden is praising his colleagues in 'Arts': "THE NOVELIST" and "THE COMPOSER". Thus, they have a common Theme: 'creativity', which the poet considers as a 'gift' $->$ it is a kind of 'key-word', common to both poems; as well as the word "wrong(s)", which is present in both poems.

These two words embody the paradox revealed by the poems: 'giff" (positive) $X$ "wrong(s)" (negative)

GIFT - 'creativity' is a divine gift: "an absolute gift",

$$
\mathrm{X}
$$

WRONG - but, in order to 'create', the artist has to "suffer dully all the wrongs of Man". 
Analysing the two poems, we perceive that they have some similarities, and also some dissimilarities; i.e., while in "The Novelist" the level of Form is foregrounded, in "The Composer" the Phonolo. gical aspect is emphasized.

The RHYME scheme seems to approach the two poems:

"The Novelist"

uniform

known

thanderstorm

olone

he

learn

be

turn

must

to

Just

too

can

Man
"The Composer

a sketches

b reject

a fetches

b b connect

c c sdaption

d $d$ rift

o

d

c contraption

d gift

e e cascading

$f \quad f$ spine

e e invading

$f \quad-g$ song

g $g$ wrong

$g \quad-f$ wine

The schemes are similar, just differing in the three last lines, where the order is inverted: $f \mathbf{g ~ g}$

However, the rhymic texture of the second poem has a wide difference in relation to the first; as we have seen the rhyming words of "The Composer" have a peculiar effect of 'hardness", due to the consonant clusters, in the 1st. stanza. However. it becomes 'softer' in the 2nd. stanza due to the ncidence of nasal sounds and sonorous vowels.

In "The Novelist", we also perceive a high incidence of nasal sounds $/ \mathrm{n} / \mathrm{ng} /$ which leads us to an interesting study of the olosive consonants (as in "The Composer") in relation to the nasals (as in "The Novelist"), based on the articulation points by Delas \& Filliolet, who classify these sounds according to their height: ${ }^{10}$

DELAS \& FILIIOLET. p. 163. 


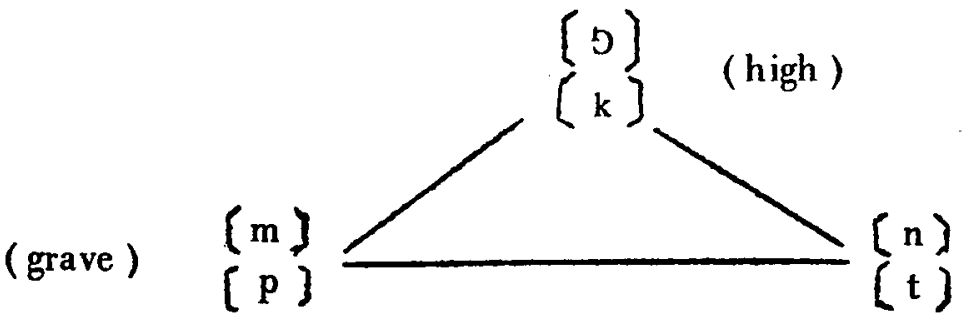

This graphic reinforces the idea of an 'opera overture' suggested by the 'high chords' of the first stanza of the poem that sings a hymn to the man who is able to create music; because of the lecurrence of plosives $/ \mathrm{p} / \mathrm{k} / \mathrm{t} /$ and nasals $/ \mathrm{n} / \mathrm{ng} /$ in the poem "The 1 Composer".

There is also a vocabulary with negative implications in both poems, which emphasizes the idea of a "claim": - The poet is complaining the unjust and bitter doom of the "artist" - the man who has the "gift of creativity", who is able to take the raw material; words, paints or notes, and make them up into a "work of art". However, such man is bound to all sort of sufferings, because he is

"One after whom none think it worth to turn ... subject to vulgar complaints" ... and "Must suffer dully all the wrongs of Man."

Thus, through "parallelisms" and other interesting devices, "The Novelist" brings forth the idea of self abnegation that is a characteristic of the artist. There is also the incidence of "simile", on the semantic level, which is evident through the repetition of "like":

$$
\begin{array}{ll}
\text { "...like a uniform," } & \text { (line 1) } \\
\text { "...like a thunderstorm", } & \text { (line 3) } \\
\text { "...like hussars"; } & \text { (line 5) } \\
\text { "...like love" } & \text { (line 11). }
\end{array}
$$

The second poem develops the same idea of the suffering process of creativity. It compares the three forms of Art or the Artist's abilities, and praises the "composer", but it also reveals the other side of the paradox (gift $X$ wrongs), pointing out the difficulties the artists have to face:

..."the painter - sketches a visible world to love or reject." (line 1) ..."the poet - fetches the images out that hurt and connect." (line 3) ..."The Composer" - "You alone, alone ... are unable to say an 
existence is wrong, and pour out your forgiveness like a wine." (line 12-14)

In a wider sense, we could say that both poems contain elements of "metapoetry", since the Poet and his work are always present through "simile" and ihrough the "Poem" by itself, as a "functioning "otality".

Finally, we realize that Auden really represents "... the artist working in the service of a cause", according to Cleanth Brooks (see D. 1), which leads us to J. Bayley's reference to Auden:

He does not imply, as Romantics like Housmann did that poetry is a pure mystery to be kept separate trom the vulgar hurly-burly of affairs. Nor it is like music. Music, like Housmann's poet.y, may cascade' in Auden's enchanting phrase - "the falls of the knee and the weirs of the spine", but poetry is rather different, not "pure contraption" but "robust game". 17

\section{BIBLIOGRAPHICAL REFERENCES}

1 AGUIAR E SILVA, Vitor Manuel. Teoria da literatura. 3. ed. Sảo Pauln, Martins Fontes. 1976. $774 \mathrm{p}$.

2 BARTHES, Roland. Elementos de semiologia. São Paulo, Cultrix, $197 \mathrm{E}$. $116 \mathrm{p}$.

2. COHEN, Jean. Estrutura da linguagem poética. São Paulo. Cultrix. 1971 $187 \mathrm{p}$.

4 DELAS. Daniel \& FILLIOLET. Jacques. Lingüistica c poética. São Paulo, Cultrix, 1975. 251 p.

5 FRYE. Northrop Anatomia da crítica. São Paulo. Cultrix. 1973. 362 p.

6 FULLER John. A reader's guide to W. H. Auden. London. Thames \& Hudson 1970. $288 \mathrm{p}$.

7 JAKOBSON, Roman. Lingüistica e comunicaçăo. São Paulo, Cultrix, 1975 $162 \mathrm{p}$.

8 LEECH, Geoffrey N. A linguistic guide to English poetry. 6. ed. London. Longman, 1977. 240 p.

S LEVIN. Samuel. Estruturas lingũisticas em poesia. Sảo Paulo, Cultrix, 1975. $108 \mathrm{p}$.

10 SPEARS, Monroe K. Auden; a collection of critical essays. Englawood Cliffs. Prentice Hall. 1964. $186 \mathrm{p}$.

11 The poetry of $\boldsymbol{W}$. H. Auden. London. Oxford University Press, 1968. $190 \mathrm{p}$. 